\title{
Three options for rebuilding the cod stock in the eastern Baltic Sea
}

\author{
Rainer Froese $^{1, *}$, Martin Quaas ${ }^{2}$ \\ ${ }^{1}$ Leibniz Institute of Marine Sciences, IFM-GEOMAR, Düsternbrooker Weg 20, 24105 Kiel, Germany \\ ${ }^{2}$ Institut für Volkswirtschaftslehre, Wirtschafts- und Sozialwissenschaftliche Fakultät, Christian-Albrechts-Universität zu Kiel, \\ Wilhelm-Seelig-Platz 1, 24118 Kiel, Germany
}

\begin{abstract}
The cod Gadus morhua stock in the eastern Baltic Sea has seen a recent miraculous recovery, mainly due to a drastic decrease in fishing mortality $(F)$. Here we explore 3 options for rebuilding the stock to the size (biomass that can produce the maximum sustainable yield, or $B_{\mathrm{msy}}$ ) that is required by international law and that can support high long-term yields. The first option implements a fishing mortality of $F=0.3$, as is aimed for under the current European Commission management plan. The second option implements in addition the current constraint of a maximum annual increase of $15 \%$ in total allowable catches until a catch corresponding to $F=0.3$ is reached. The third option freezes the 2010 catch for 2 yr before allowing a linear increase with spawning stock biomass towards $90 \%$ of the maximum sustainable yield. We show that the first option provides the highest catches for the first $3 \mathrm{yr}$, but fails to rebuild the biomass to the level of $B_{\mathrm{msy}}$. The second option rebuilds the biomass above $B_{\mathrm{msy}}$ only temporarily and results in the lowest catches over a $10 \mathrm{yr}$ period. The third option rebuilds the biomass above $B_{\text {msy }}$ and provides high catches and the highest profit within 10 yr. Within a decade, all 3 options provide several-fold higher biomasses, catches, and profits compared to the current situation, underlining the benefits that can be obtained from proper fisheries management. In comparison, the so-called precautionary management approach $(F=0.6)$ implemented until 2006 would perform worse in every respect.
\end{abstract}

KEY WORDS: Cod · Maximum sustainable yield $\cdot$ Eastern Baltic Sea $\cdot$ Stock recovery $\cdot$ Profitable fisheries Resale or republication not permitted without written consent of the publisher

\section{INTRODUCTION}

Cod Gadus morhua in the eastern Baltic Sea has a long history of over-exploitation, with fishing mortalities $(F)$ as high as 1.5 in 2004 (ICES 2010). Due to several coincidences, including 2 slightly improved recruitment events and political changes in a European Union member state, the fishing pressure in 2010 fell to $F=0.23$ (ICES 2010) and the stock recovered to about one-third of the size ( $B_{\mathrm{msy}}$, the biomass that can produce the maximum sustainable yield, MSY) that would produce the MSY (Froese \& Proelß 2010). Rebuilding stocks to $B_{\mathrm{msy}}$ is a requirement under the Law of the Sea (UNCLOS 1982) and has been given the political deadline of 2015 by the Johannesburg Summit on Sustainable Develop- ment (JPOI 2002). A multi-annual management plan for the eastern Baltic cod stock has been proposed by the European Commission (EC 2007) and has been under implementation since 2008. This management plan aims for a fishing mortality of at least $F=0.3$, constrained by a maximum change in total allowable catch (TAC) of $15 \% \mathrm{yr}^{-1}$ if $F<0.6$. The spawning stock biomass (SSB) was estimated at $294330 \mathrm{t}$ at the beginning of 2010 and landings were predicted at $56800 \mathrm{t}$ by ICES (2010). Using these numbers as a start, we simulated the development of SSB, catches, and profits under 4 different management options. The $F 0.6$ option shows the past Common Fisheries Policy where SSB was kept at the border of presumably safe biological limits, with a 'precautionary approach' fishing mortality 
$F_{\mathrm{pa}}=0.6$ as a target reference point (Lindegren et al. 2009). The $15 \%$ option implements the 2008 management plan with a maximum $15 \%$ increase in annual catches until a catch equivalent to a fishing mortality of $F=0.3$ is reached. The $F 0.3$ option removes the $15 \%$ constraint on TAC increase, as has apparently already been requested by some fishers (W. W. F. Poland pers. comm.). The HCR (Harvest Control Rule) option maintains the catch taken in 2010 until a biomass larger than $0.5 B_{\mathrm{msy}}$ is reached. It then increases catches linearly with SSB towards a maximum of $90 \%$ of MSY, as has been proposed as a generic harvest control rule for European fisheries (Froese et al. in press).

\section{MATERIALS AND METHODS}

We used an age-structured model with 8 age groups as in the respective standard assessment conducted by the Baltic Fisheries Assessment Working Group of ICES (ICES 2010). We used natural mortality, maturity ogive, and weights-at-age in the stock, as given by the ICES. We assumed an age-specific relative fishing mortality of $0.6 \mathrm{~F}$ at age $2,0.8 \mathrm{~F}$ at age 3 , and $1.0 \mathrm{~F}$ for all subsequent age groups. For short-term forecasting, ICES uses the geometric mean of recruitment of past years; but for simulations such as the evaluation of the EC management plan, they used a hockey-stick relationship (ICES 2010). For our simulations we followed that approach and used a smooth hockey-stick function (Froese 2008) with parameters from Froese \& Proelß (2010) to model recruitment. Annual profits were equal to revenues from selling the catch minus fishing costs. We used the Spence (1974) cost function, where fishing costs are proportional to fishing mortality $F$. To estimate the cost parameter we followed the approach of Kronbak (2005), updated with more recent Danish data (Fiskeriregnskabsstatistik 2007), which yields fishing costs of $92.3 \times F$ in millions of euros. We furthermore assumed that the price of cod would remain at the European reference price of 1095 euros $\mathrm{t}^{-1}$ in 2010, which is the lowest price at which imports of cod into the European Union are allowed (EC 1999, 2009). With this assumption, we obtain a very conservative prediction of future profits, as the ex-vessel price of cod usually was much higher than this reference price, in particular for older and larger cod. For the HCR option, we used values of MSY $=255735 \mathrm{t}$ and $B_{\mathrm{msy}}=997248 \mathrm{t}$ as given in Froese \& Proelß (2010), with $95 \%$ confidence limits of 171282-384346 $t$ and 707 105-1406344 t, respectively. The model with the 4 different management options was implemented in Matlab (version R2009a); the source code is available in Supplement 1 (www.int-res.com/articles/suppl/ m434p197_supp/).

\section{RESULTS AND DISCUSSION}

We followed Froese \& Proelß (2010) in assuming an SSB of close to 1 million t for $B_{\mathrm{msy}}$. This is also the biomass level reached in our simulation with the geometric mean of past recruitments and a catch of 0.9 MSY. Several colleagues (pers. comm.) have expressed their doubt that the Baltic can support such a high biomass of a top predator. The highest biomass on record is about 0.7 million $t$ in 1980, reached after several years of high fishing pressure well above the level of fishing mortality resulting in MSY $\left(F_{\text {msy }}\right)$. The catch in 1980 was 350000 t; i.e. had it not been taken, SSB would have surpassed the 1 million t mark. These data demonstrate that in the recent past, the Baltic has supported a large and highly productive cod stock. The surplus production (increase in total biomass + landings + discards) of the eastern Baltic cod in 2009 was over $100000 \mathrm{t}$, showing a strong current growth potential. Thus, we believe the $B_{\mathrm{msy}}$ used here is not unrealistic. Even if a lower value for $B_{\text {msy }}$ was assumed, that would not change the performance of the examined management options relative to each other, the main topic of the present study.

The results of our simulations can be seen in Fig. 1. None of the options rebuilds the stock to $B_{\mathrm{msy}}$ in 2015, thus failing the requirement of the Johannesburg Plan of Implementation (JPOI 2002). Maintaining the 2010 catch level for several more years or a complete closure of fishing for $2 \mathrm{yr}$ would have achieved that. The HCR option reaches $B_{\mathrm{msy}}$ in 2021 and stays above that reference point thereafter. The $15 \%$ option reaches $B_{\mathrm{msy}}$ in 2017 but drops below $B_{\mathrm{msy}}$ in 2025 and stays below thereafter. The $F 0.3$ option never reaches $B_{\text {msy' }}$ because $F=0.3$ is apparently larger than the fishing mortality resulting in $B_{\text {msy }} . F_{\text {msy }}$ was estimated for this stock as $F=0.19$ by Froese \& Proelß (2010). Under the $F 0.6$ option, catch and profits would be highest in the period 2011 to 2013. However, SSB would decrease from 2011 onwards, with catches and profits falling far below all other options from 2016 onwards.

Froese et al. (in press) expect fishing at 0.9 MSY to result in a biomass of about $1.3 B_{\text {msy. }}$ Our model resulted instead in a biomass of $1.1 B_{\text {msy }}$ in 2040, the last year of our simulations, where biomass still increased under the HCR option. We suspect that this slow growth in biomass is due to the limited number of age classes and the fixed age-specific fishing mortality in our model. The impact of catches on stock biomass would be less and thus biomass would be higher if catches were mostly taken from the age class where cohort biomass is maximum, which is at about $8 \mathrm{yr}$ of age for Baltic cod (Bethke 2005, Froese et al. 2008).

Initial catches are higher under the $F 0.3$ option than the catches under the HCR option for the first $3 \mathrm{yr}$ but are then about equal and subsequently lower. The sum 

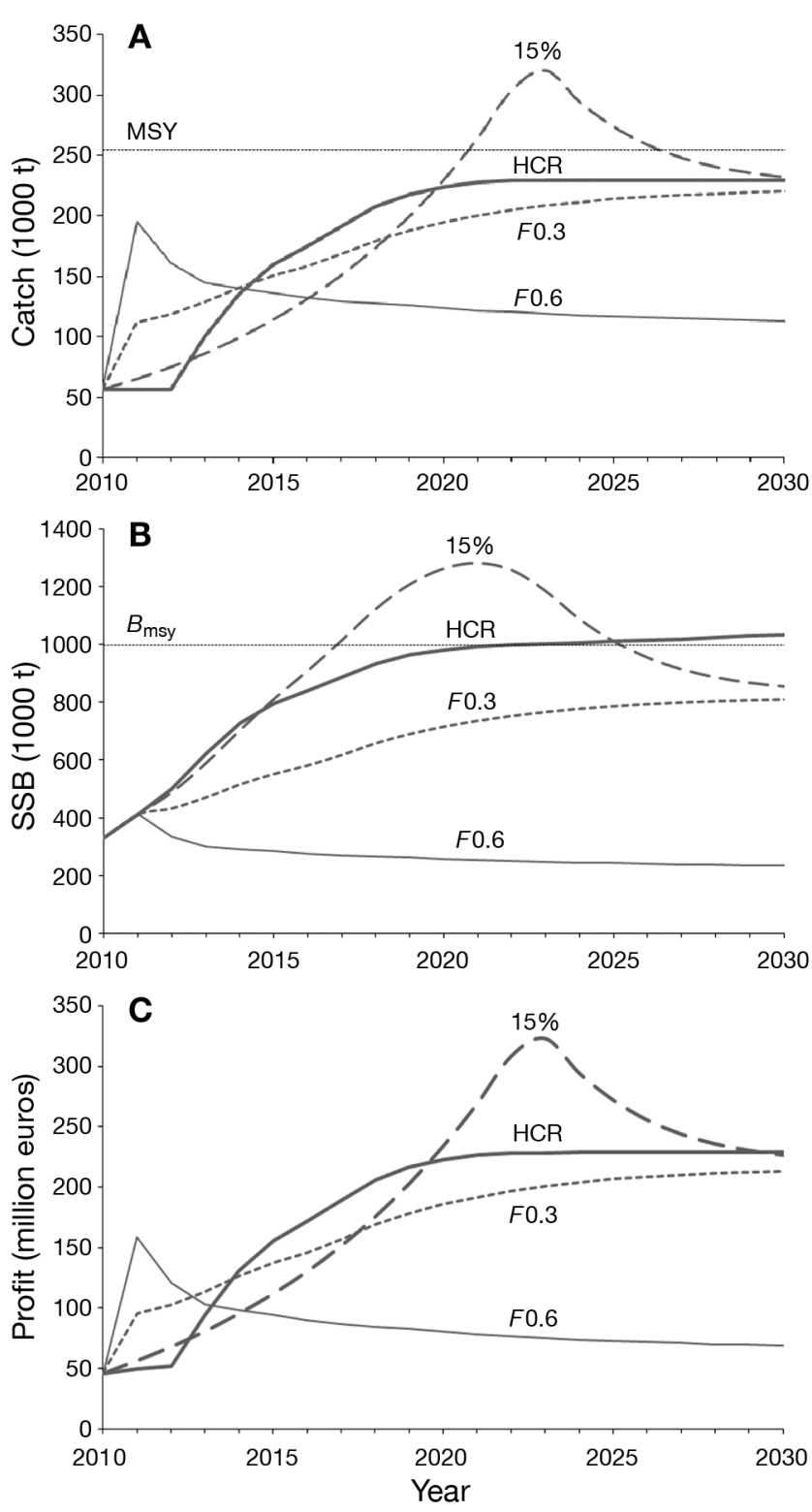

Fig. 1. Simulated (A) catches, (B) spawning stock biomass (SSB), and $(C)$ profits for eastern Baltic cod, resulting from 4 different management options ( $F 0.6=$ past management plan, $F 0.3$ $=$ current goal for fishing mortality, $15 \%=$ current management plan, HCR = Harvest Control Rule proposed by Froese et al. in press). The dotted horizontal line shows (A) maximum sustainable yield (MSY), and (B) the biomass that would result from the maximum sustainable yield $\left(B_{\mathrm{msy}}\right)$

of catches from 2010 to 2020 are about identical under the $F 0.3$ and HCR options but $23 \%$ lower under the $15 \%$ option. The peak in catches under the $15 \%$ option results from the high biomass that is temporarily built up under that option, due to the initial slow increase in catches. While it may be tempting to take such catches well beyond MSY, this would provide incentives for overcapacity and flood the market with cod, probably resulting in low prices and usage as fish meal.
In the long term, $F 0.3,15 \%$ and HCR produce similar high catches close to $0.9 \mathrm{MSY}$, but only the HCR option does that from a biomass larger than $B_{\text {msy }}$. In other words, $F=0.3$ and $F=0.6$ are both on the wrong side of the 'hump' in a surplus-yield model. Because of the higher biomass and thus lower marginal fishing cost, long-term profits are highest under the HCR option, already from 2014 onwards, higher than under the $F 0.3$ option.

Froese et al. (in press) suggest that long-term catches in Europe could be $63 \%$ higher on average under their proposed harvest control rule. In the case of the eastern Baltic cod, because it was so heavily depleted, our simulations suggest that catches and profits may increase more than 3 -fold in only $10 \mathrm{yr}$. Increased catches and profits in the eastern Baltic cod fishery under the recovery plan of 2008 were also obtained in simulations by Bastardie et al. (2010), even under assumptions of low recruitment. Similarly, substantial increases in profits from Baltic cod fisheries resulted from simulations by Bethke $(2005,2006)$ when minimum age at first capture was set between 4 and 8 yr. Sparholt et al. (2007) conducted a meta-analysis of ICES stocks and concluded that by reducing fishing mortality, yield could be more than doubled over current yield in demersal stocks such as cod. Lindegren et al. (2009) explored management options for the eastern Baltic cod stock. They concluded that an adaptive management system that reduces fishing mortality when environmental conditions are unfavorable would have prevented the collapse of the stock and would increase stock size and profits. However, their proposed fishing mortality ranges from $F=0.43$ at a zero discount rate to $F=6.3$ at a 0.15 discount rate, i.e. well above $F_{\text {msy }}$ and thus preventing a true recovery of the stock (see biomass development under the F0.6 option in Fig. 1B). Döring \& Egelkraut (2008) analyzed the economics of the Baltic cod fishery and concluded that, given the growth potential of the stock, it makes perfect economic sense to invest in future stock sizes.

The development of profits (revenues minus fishing costs) shown in Fig. $1 \mathrm{C}$ are parallel to the development of catches (Fig. 1A) for the options with a constant $F$. This has 2 reasons: (1) we made the conservative assumption that there is no price premium for larger cod and (2) we used the Spence cost function where fishing costs are proportional to $F$. Thus, for the options with a constant $F$, fishing costs are constant. For the HCR option, profits and catches evolve differently, because here larger stock size decreases the cost of fishing. This can be already seen for the years 2010 to 2012, where profits increase slightly despite constant catches. Also, profits in 2014 under the HCR option are already larger than under the F0.3 option, although catches are still smaller. These effects would be even 
stronger if better prices for larger cod had been factored in.

We used standard assumptions about future recruitment and rates of natural mortality and prices from 2007. Actual recruitment will be different, as abandoned spawning areas (ICES 2010) may not be recolonized immediately and areas with oxygen depletion remain a concern, and although sprat biomass as prey for cod is high, sprat are fished beyond $F_{\text {msy }}$ and that stock may decrease in size. Clearly, the management goals for cod and sprat fisheries need to be harmonized (Köster et al. 2003). As a result of many factors such as indicated here, catch and biomass levels may be reached earlier or later than proposed. Also, current ex-vessel prices for Baltic cod (and, hence, profits) are much higher than the 2010 European reference price that we assumed for our simulations. But since all 4 options used the same assumptions, the relative differences between them are likely to hold true. We hope that our simulations will inspire the future management of the eastern Baltic cod. The 3 new options now available to management are far better than the past situation, with the potential of providing several-fold higher biomasses, catches, and profits within a decade, without pain for the fishers. But only the HCR option fully rebuilds the stock, thus satisfying environmental demands and international obligations while providing the highest profit.

Our results can be summarized as follows: after years of misery under so-called precautionary management, the eastern Baltic cod stock is clearly and quickly recovering under the new MSY-oriented management regime. Rather than demanding the highest possible catches immediately, fishers would be well advised to demand low increases in catches and a fixed upper catch below the theoretical maximum once the stock is fully recovered (the HCR option). Doing so may increase their profits 3-fold in 5 yr.

Acknowledgements. We thank C. Zimmermann for critical comments on an earlier version of this manuscript. This study was supported in part by the Future Ocean Excellence Cluster 80, funded by the German Research Foundation on behalf of the German Federal and State Governments.

\section{LITERATURE CITED}

Bastardie F, Nielsen JR, Kraus G (2010) The eastern Baltic cod fishery: a fleet-based management strategy evaluation framework to assess the cod recovery plan. ICES J Mar Sci 67:71-86

Bethke E (2005) Gewinnmaximierung der Fischerei schützt den Dorsch der westlichen Ostsee vor Überfischung - nur

Editorial responsibility: Konstantinos Stergiou,

Thessaloniki, Greece ein theoretischer Ansatz? Inf Fisch-forsch 52:12-20

> Bethke E (2006) Begrenzung des Fischereiaufwandes oder Erhöhung der Mindestmaschenöffnung - ein Vergleich der Alternativen bei der Dorschfischerei in der Ostsee. Inf Fisch-forsch 53:13-22

Döring R, Egelkraut T (2008) Investing in natural capital as management strategy in fisheries - the case of the Baltic Sea cod fishery. Ecol Econ 64:634-642

EC (European Commission) (1999) Council Regulation (EC) No. 104/2000 on the common organization of the markets in fishery and aquaculture products. EC, Brussels

EC (2007) Council Regulation (EC) No. 1098/2007 establishing a multi-annual plan for the cod stocks in the Baltic Sea and the fisheries exploiting those stocks, amending Regulation (ECC) No 2847/93 and repealing Regulation (EC) No 779/97. EC, Brussels

EC (2009) Commission Regulation (EU) No. 1280/2009 fixing the reference prices for certain fishery products for the 2010 fishing year. EC, Brussels

Fiskeriregnskabsstatistik (2007) Account statistics for fishery. Ministeriet for Fødevarer, Landbrug og Fiskeri, Statens Jordbrugs- og Fiskeriøkonomiske Institut, Copenhagen (2007, and previous editions from 2000 onwards)

Froese R (2008) The continuous smooth hockey stick: a newly proposed spawner-recruitment model. J Appl Ichthyol 24: 703-704

Froese R, Proelß A (2010) Rebuilding fish stocks no later than 2015: will Europe meet the deadline? Fish Fish 11:194-202

> Froese R, Stern-Pirlot A, Winker H, Gascuel D (2008) Size matters: how single-species management can contribute to ecosystem-based fisheries management. Fish Res 92: 231-241

Froese R, Branch TA, Proelß A, Quaas M, Sainsbury K, Zimmermann $\mathrm{C}$ (in press) Generic harvest control rules for European fisheries. Fish Fish doi: 10.1111/j.14672979.2010.00387.x

ICES (International Council for the Exploration of the Sea) (2010) Report of the Baltic Fisheries Assessment Working Group. ICES CM 2010/ACOM:10. ICES, Copenhagen

JPOI (Johannesburg Plan of Implementation) (2002) The plan of implementation of the World Summit on Sustainable Development. Adopted 4 Sep 2002 at the World Summit on Sustainable Development, Johannesburg, South Africa

Köster FW, Möllmann C, Neuenfeldt S, Vinther M and others (2003) Fish stock development in the Central Baltic Sea (1976-2000) in relation to variability in the physical environment. ICES Mar Sci Symp 219:294-306

Kronbak LG (2005) The dynamics of an open-access fishery: Baltic Sea cod. Mar Resour Econ 19:459-479

Lindegren M, Möllmann C, Nielsen A, Stenseth NC (2009) Preventing the collapse of the Baltic cod stock through an ecosystem-based management approach. Proc Natl Acad Sci USA 106:14722-14727

Sparholt H, Bertelsen M, Lassen H (2007) A meta-analysis of the status of ICES fish stocks during the past half century. ICES J Mar Sci 64:707-713

Spence AM (1974) Blue whales and applied control theory. In: Gottinger HW (ed) System approaches and environmental problems. Vandenhoeck and Ruprecht, Göttingen, p 97-124

UNCLOS (1982) United Nations Convention on the Law of the Sea. 1833 UNTS 3. Available at: www.un.org/Depts/los/ convention_agreements/texts/unclos/unclos_e.pdf

Submitted: October 28, 2010; Accepted: June 7, 2011

Proofs received from author(s): July 13, 2011 